\title{
Social Criticism in Indonesian Literary Works during the New Order Era
}

\author{
I Ketut Sudewa \\ Udayana University \\ Email: sudewa.ketut@yahoo.co.id
}

\begin{abstract}
The literary works written and published during the New Order era were used as the data in this article. During this era there were many literary works which contained social criticisms towards the New Order government. The study focuses on the literary work in the form of poems, and employed the qualitative research method. The theory of literary sociology was used as the main theory while the structural theory and semiotic theory were used as the supporting theories. The social criticisms and meaning which were transmitted by the poets through their poems could be optimally revealed using these theories. The result of the study shows that the poems written by the poets during the New Order era, especially those written by Taufiq Ismail contained a lot of social criticisms; he criticized the law, human rights, politics, education and economy implemented by the New Order government. Such social criticisms were shown through different poetic elements such as the diction, language style, and rhetoric. The social criticisms expressed by Taufic Ismail reflected that Indonesia (the readers) should refer back to the nation's identity and character as stated in the Five Principles 'Pancasila' and the 1945 Constitution.
\end{abstract}

Keywords: social criticism, reconstruction, identity, character, poems

\section{INTRODUCTION}

Men and women of letters are one of the nation's elements who were brave enough to criticize the New Order government's policies and actions through the literary works they wrote. They criticized all forms of injustice which were felt by most of the Indonesian people. They did not pay attention to the risks which they would possibly bear for what they had done. As a consequence, many literary works, for example, the ones which were written by Pramudya Anantatoer, W.S. Rendra, Wiji Thukul, Ratna Rarumpet, and Riantiarno were prohibited to be circulated; moreover, W.S. Rendra and some others were arrested without being brought to trial (Haryono, ed., 2009: 65-66).
Then the literary works written by Taufiq Ismail, Ramadhan KH, Sori Siregar, and so forth which also contained social criticisms appeared. However, what they underwent was not as bad as what the others did. What was described above proves that literary works could be socially used to control the New Order government. At least such a government was afraid that the literary works could make the Indonesian people aware of what they, as citizens, were socially, economically, culturally, legally, and politically entitled to. The literary works written by W.S. Rendra such as Blues Untuk Bonnie (Poetry Anthology, 1981), Potret Pembangunan Dalam Puisi (Poetry Anthology, 2006), Mastodon dan Burung Kotor (Drama Text, 1972), Kisah Perjuangan SukuNaga (Drama 
Text, 1975), and SEKDA (Drama text, 1977), for examples, criticized the New Order government's policies which always protected the capitalists and treated people in an authoritative manner. In addition, such literary works also criticized that there was a socio-economic gap, the New Order government was corrupt, and that how the New Order government treated people tended to deviate from the human rights. The poems entitled Tirani dan Benteng(1993) and Malu Aku Jadi Orang Indonesia (1998) which were written by Taufiq Ismail, criticized the socio-political life during the New Order era; the poem written by LadangPerminus (1990) and the poem written by Sori Siregar entitled Awal Pendakian (1985) criticized that there were many corruptions taking place during the same era. As the Indonesian literary works which criticized the New Order government included proses, poems and dramas, this present study only investigates the poems written by Taifiq Ismail as stated above. The social criticisms which the poems and dramas written by W.S. Rendra contained were already explored by Sudewa (2012).

Based on the background described above, the problems of the present study are formulated as follows. (1) What types of social criticisms were transmitted by Taufiq Ismail through his poems? (2) How did Taufiq Ismail transmit social criticisms through his poems? And (3) what were the nation's identity and characterwhich were intended by Taufic Ismail through the social criticisms which his literary works contained?

The theory of literary sociology was used as the main theory and the structural theory and the theory of semiotics were used as the supporting theories in this present study. The theory of literary sociology is proposed by Diana Laurenson and Alan Swingewood (1972), the structural theory is proposed by Pradopo (2002) and Teeuw (1984), and theory of semiotics is proposed by Hawkes (1978). The textual approach and qualitative method were used, meaning that the data were taken from the poetry texts written by Taufic Ismail. The collected data were identified and analyzed qualitatively, giving emphasis on the quality of the research finding. The techniques used to collect the data were reading, observing, identifying, and classifying. Such method and techniques were used at the same time to answer the problems of the study.

\section{SOCIAL CRITICISMS IN THE POEMS WRITTEN BY TAUFIQ ISMAIL}

Economy was one of the sectors which was criticized by Taufic Ismail. Such a sector is concerned with two things; they are poverty and unemployment which were undergone by the Indonesian people. Poor people refer to those who are not able to satisfy their basic needs as human beings such as food, clothing and housing (Sudewa, 2012: 111). Poverty causes the quality of the people's lives to be low. Chambers (1983: 109) and Soetrisno (1997: 18) refer to such a condition as "integrated poverty". Poverty results from the "misfortune" in different aspects of life which are related to one another. In accordance with Chambers "misfortune" includes (1) poverty; (2) physical weakness; (3) vulnerability; (4) isolation; (5) powerlessness.

Taufic Ismail criticized the matters pertaining to economy especially poverty, unemployment, and capitalism which took place in Indonesia during 1990s, as shown by the following poem entitled "Seratus Juta" (One Hundred Million).

Ummat miskin dan pengganggur berdiri hari ini

Seratus juta banyaknya, tampakkah olehmu wajah mereka

Di tengah mereka tak tahu aku akan berbuat apa

Kini kutundukkan kepala, karena

Ada sesuatu besar luar biasa

Hilang terasa dari rongga dada

Saudaraku yang sirna nafkah, tanpa kerja berdiri di sini

Saudra kita yang sempit rezeki, terbungkuk hari ini

Di belakang mereka tegak anak dan istri, berjuta-juta

Beratus ribu saf berjajar susunannya

Sampai ke kakilangit khatulistiwa

Tak ada tempat lagi tersedia

Di kantor, pabrik dan toko bagi mereka

Dan jadi semestalah ini sengsara

Anak-anak tercerabut dari pendidikan

Penyakit dan obat, sejarak utara dan selatan 
Cicilan kridit terlantar berantakan

Bilakah gerangan terbuka gerbang pekerjaan (Ismail, 1998: 5-6).

The free translation is as follows:

The poor and unemployed are standing

They total one hundred million, can you see their faces

I am among them and do not know what I can do for them

I am bowing my head, as

There is something which is extremely serious

Disappearing from the thoracic cavity

My brothers who earn nothing and are unemployed are standing here

Our brothers with a limited access to income are bending

Their children and wives, totaling millions, are behind them

They are standing in hundreds of thousand rows There are so many that they reach the horizon of the equator

There is no space

At the office, factory, and shop for them

Such a misery is becoming universal

Their children do not go to school

The medicine they need for the diseases they may suffer from is unaffordable to them They are not able to pay for installments When on earth job opportunities will be available for them

(Ismail, 1998: 5-6)

From the semiotic point of view, the above poem shows that Taufiq Ismail strongly described the Indonesia's condition when the New Order government was about to come to an end. Structurally, the poet used strong rhetoric and diction to describe the poverty which was undergone by more or less 'one hundred million' Indonesian people. The poet described the strength of the 'one hundred' poor and jobless Indonesian people using the words 'berdiri hari ini' (standing today). Although there were "one hundred million' Indonesian people who were poor and unemployed, in accordance with the poet, they were strong and rigid enough to live their lives. Seeing such a condition, the poet asked the readers and government 'whether they can see the faces of those' who were poor and unemployed. From the semiotic point of view, such a question to which no answer was needed contained a very strong social criticism; the reason was that both the readers and government ('olehmu') could not see and did not pay any attention to their lives. The semiotic meaning of such an expression indicated that the government did not pay any attention to the poor people. The aesthetic value of such an oratorical question was so strong that it touched the readers or the government. Both the readers and government should have paid attention to the suffering which was undergone by one hundred million Indonesian people.

The poet, as one of those people, was a common individual (someone who did not have power); as a result, there was a psychological conflict within himself. On one hand, he was sad that there were so many people who were poor and jobless; on the other hand, he was a common individual and one part of the poverty; therefore, he did not have power to change it. The poet could only sarcastically said 'aku akan berbuat apa' (what I will do). He could only say: /Kini kutundukkan kepala/ (Now I'm bowing my head), as he was sad, he said: /Ada sesuatu besar luar biasa/ (There's something which is extremely serious), /Hilang terasa dari rongga dada/ (disappearing from the thoracic cavity)/. In this case, what was meant by something which was so serious and disappeared in the thoracic cavity was the condition in which there were so many poor and unemployed people. From the semiotic point of view, something referred to the heart and the feeling of being sympathetic which the government should have had.

The poet referred to the Indonesian people as 'saudaraku' (my brothers) who had lost their jobs 'nafkah' (income), and said that there were no job opportunities available for them ('sempit rezeki'). He criticized such a condition by saying: /Taka da lagi tempat tersedia/ (there was no space for them), /di kantor, pabrik dan toko bagi mereka/ (at the office, factory, shop), /Jadi semestalah ini sengsara/ (Misery was getting universal). He said such things to express that the people's misery was perfect. Such choices of words (diction) strongly expressed that the poet was very sad and worried. Aesthetically, such choices of words were used 
to express his sympathy and empathy towards the people's condition ('semestalah ini sengsara' (misery was becoming everywhere). The poet saw that there were so many people who were unemployed ('tanpa kerja'), powerless and bowing their heads ('terbungkuk hari ini'). Furthermore, he said that /Di belakang mereka tegak anak dan istri/ (their children and wives were behind them), /Beratus ribu saf berjajar susunannya/(they were standing in hundreds of thousand lines). There were so many unemployed people, and their families were standing in queue ('berjajar') and expecting for job opportunities. Such a condition was expressed through the line: /Sampai ke kakilangit khatulistiwa/ (they reach the horizon of the equator).

Such a sociological condition caused the poet to say that /anak-anak terecerabut dari pendidikan/ (the children do not go to school), / Penyakit dan obat, sejarak utara dan selatan/ (the medicine they need for the diseases they may suffer from are unaffordable). From the semiotic point of view and sociological point of view, the poet would like to say that poverty and unemployment caused the children not to be able to go to school or to discontinue school. He chose the word 'tercerabut' (being uprooted) to express the children's education. Diseases spread all over the archipelago ('utara dan selatan'/from the north to the south), and the people could not afford to buy medicine. Poverty and unemployment did not only cause the children to discontinue school but it also affected the other aspects of life. The poet expressed such a condition through the line: / Cicilan kridit terlantar berantakan/ (being unable to pay in installments). Economically, the poor people who were accustomed to buying things in installments to satisfy what they needed 'terlantar berantakan' (being left unpaid); the reason was that they were not able to pay such things in installments 'cicilan'. The poet chose the word 'berantakan' (being unpaid). Aesthetically, such a word was appropriately used to describe such a bad economic condition resulting from poverty and unemployment. Finally, seeing such a condition, he criticized the government using a pessimistic question: /Bilakah gerangan terbuka gerbang pekerjaan/ (when on earth job opportunities will be made available). He indirectly suggested that the government should create as many job opportunities as possible in order to reduce or abolish poverty. That was what the government was obliged to do for the people. He described the sociological atmosphere of the Indonesian society when this poem was written through the line: /Suram, suramnya langit keadaan/, /Nestapa, nestapanya cuaca bangsa/ (the national atmosphere was gloomy and sorrow).

He used the power of repeated sounds; the word 'suram' (gloomy) and the word 'nestapa' (sorrow) were repeated; therefore, aesthetically, the poet made those who did not see and experience such poverty and unemployment imagine them and finally feel what made him sad. As a citizen, he was powerless and embarrassed when he saw such a condition in Indonesia by saying: 'Kini kutundukan kepala' (Now I'm bowing my head). According to him, such a condition resulted from /Ada sesuatu besar luar biasa/ (There's something which is extremely serious) and /telah hilang terasa dari rongga dada/penguasa atau pemerintah' (it has disappeared from the thoracic cavity/the ruler/ government). From the semiotic point of view, 'sesuatu yang besar luar biasa yang telah hilang' (something which is extraordinarily serious and has disappeared) referred to apprehension, social solidarity, sympathy, the nation's responsibility in general and the government in particular.

Then, in the next couplets of the poem "Seratus Juta" (One hundred million) above, the poet described the endemic consequence of poverty and unemployment using monologues. Such a technique sharpened and strengthened the poet's social criticism. The seven couplet poem, each is made up of three lines and each couple starts with the line /Dari yang seratus juta itu/ (Out of one hundred million) was used by the poet to give emphasis that there were one hundred million poor people in Indonesia. Through such a sevencoupletpoem, the poet asked questions and such questions were anwered by him (monologue). The monologues made by the poet in such a sevencouplet poem can be summarized as follows.

The poet asked: /Dari yang seratus juta itu/ (Out of one hundred million people), 'berapa' (how many) who : 'putus kerja dan makan setengah kali sehari' (losing livelihood and having half a meal a day), 'sakit ginjal, hamil tua dan radang paru-paru' 
(suffering from kidney disease, advanced stage of pregnancy and pneumonia), 'bayi yang tidak dapat susu dan makanan tambahan' (the infants that do not consume milk and supplementary food), 'anak yang putus sekolah dan habis kontrakan rumah' (the children who discontinue school and those who cannot extend the lease of the house), 'berubah ingatan dan semakin ditimbun hutang' (those who are getting made and indebted), 'orang tertawa-tawa sendiri dan berniat bunuh diri' (those who laugh at themselves and intend to commit suicide), 'orang yang penyakitan dan akan dikubur mati kelaparan' (those who are easily getting sick and will die of starvation). All the questions were answered by the poet by saying: 'Aku tak tahu' (I don't know), 'Bagaimana aku bisa tahu' (how can I know), 'Betul-betul aku tak tahu' (I really do not know), 'Jangan tanya padaku' ( don't ask me), 'Mengapa kau bertanya begitu' (why do ask in such a way), 'Alangkah tak pantasnya pertanyaan itu' (such questions are not good), and "Sudah, sudah cukup dan hentikan semua pertanyaan itu' (That's enough, stop such questions). From the semiotic point of view, the questions given by the poet in the monologues above indicated that it was the ruler or government which should have answered them instead of himself. From the semiotic point of view, the answers given by the poet in the monologues above indicated that it was the government which should have answered such questions instead of him. If the poet was continuously asked to answer such questions, he would be unhappy and said: /Sudah, sudah cukup dan hentikan semua pertanyaan itu/ (that's enough, stop asking such questions). The social criticisms which were expressed through the monologues above, what was intended by the poet would be getting stronger and easily understood by the readers. The important things which were emphasized by the poet were expressed through repeated sounds. Such a technique also aesthetically affected the readers.

The poet also expressed his social criticisms towards capitalism through another poem entitled "Malu (Aku) Jadi Orang Indonesia" (I feel embarrassed that I am an Indonesian). Pay attention to the following quoted couplets.

Di negeriku dibakar pasar pedagang jelata supaya berdiri pusat

Belanja modal raksasa,

Di negeriku Udin dan Marsinah jadi syahid dan syahidah,

Ciumlah harus aroma mereka punya jenazah, sekarang

Saja sementara mereka kalah, kelak perencana dan

Pembunuh itu di dasar neraka oleh satpam akhirat akan

Diinjak dan dilunyah lumat-lumat, (Ismail, 1982: 20)

The free translation version is as follows In my country the market where the small traders sell their commodities are burned in order to build a huge shopping center In my country Udin and Marsinah were martyrs, smellthe aroma of their corpses, now they are defeated, but then those who planned and killed the two people will go to hell and will be stepped on

and crushed to bits by the heaven's security (Ismail, 1998: 20).

In Indonesia the capitalist always intends to control all sectors of the Indonesian people's lives in general and the economic sector in particular. Such a condition was observed by the poet; therefore, he criticized the ruler or the government. The poet said that 'Di Negeriku' (In Our country, Indonesia), the traditional market symbolized the common people's economy or what was referred to as 'pedagang jelata' with limited capital. They were marginalized and 'dibakar' (they were burned) so that a capitalist trading center could be built. The capitalist had 'modal raksasa' (huge capital); in other words, the huge capital symbolized the capitalist. They built modern shopping centers such as supermarkets (Mall) with unlimited capital. The consequence was that the 'pedagang jelata' (the small traders) became marginalized and defeated in competition and the capitalists with their 'modal raksasa' (unlimited capital) were controlling the Indonesia's economy.

The poet criticized what the capitalists had done in Indonesia to control every type of capital in Indonesia. In addition, they did what they could do to achieve their goal. The capitalists did 
not hesitate to marginalize and even kill those who were brave enough to criticize their action and collaboration with the ruler. Marsinah, a labourer, and Udin, a journalist who was killed in Yogyakarta exemplified this. They were two minor victims of the crime conspiracy between the ruler and the capitalists. Marsinah, who was a laborer employed at a factory in East Java, was killed for strongly struggling for the laborers' rights which were broken by the capitalists. Udin was killed as he wrote an article which blamed the ruler.

Taufiq criticized the events which happened to the two unimportant warriors mentioned above by saying /Di negeriku Udin dan Marsinah jadi syahid dan syahidah/ (In our country Udin and Marsinah were martyrs). In accordance with the poet, their deaths were not common ones; they died as warriors; therefore, they were referred to as syahid and syahidah, namely, they died for the religion they adhered to (KBBI, 2011: 1367). Their glory and sacrifice left 'arum aroma' (fragrance) for the common people. The poet believed that those who had killed Udin and Marsinah would get equal punishment. He said that those who had planned and killed Udin and Marsinah would be 'di dasar neraka' (in the base of the hell) and they would be stepped on and crushed to bits by 'satpam akhirat' (the heaven's security).

The words 'dilunyah' and 'lumat-lumat' (being crushed to bits) were chosen by the poet. Aesthetically, the poet would like to give strong imagination to the readers that he hated those who had killed Udin and Marsiah. The poet was successful in achieving the goal through such choices of words. The social criticism towards the government, as far as capitalism is concerned, was also expressed by W.S. Rendra in his poem entitled "Sajak Burung-burung Kondor" as already discussed by Sudewa (2012:215-228).

Taufiq Ismail also criticized the politics of the New Order government through his poems (Sudewa, 2012:245-252). Politics cannot be separated from power (Alfian, 2003:173). However, the reality in society shows that politics is negatively defined as an attempt made to maintain or struggle for power. Everything should be done in order to maintain and struggle for power; therefore, the law, aesthetics and morality are often broken to maintain and struggle for power
(Sudewa, 2012:245-246). That is why politics is directly and indirectly related to the law and human rights. As far as politics is concerned, Taufiq Ismail expressed his social criticism through the following poem entitled "Sebuah Jaket Berlumur Darah" (a blood-smeared jacket) as follows.
Spanduk kumal itu, ya spanduk itu
Kami semua telah menatapmu
Dan di atas bangunan-bangunan
Menunduk bendera setengah siang
Pesan itu telah sampai ke mana-mana
Melalui kendaraan yang melintas
Abang-abang beca, kuli-kuli pelabuhan
Terikan-terikan di atap bis kota, pawai-pawai perkasa
Prosesi jenazah ke pemakaman
Mereka berkata
Semuanya berkata
LANJUTKAN PERJUANGAN! (Ismail, 1993: 67)

The free English version is as follows.

The street banner is that one

We all observe you

And over the buildings

The flags are attached to the middle of the poles

Such a massage has been everywhere

Through passing vehicles

The beca (three cycled- vehicle) drivers, harbor laborers

The scream from the roofs of the city buses, brave processions

Processions of corpses to the cemetery

They say

Everybody says

KEEP GOING WITH THE OPPOSITION! (Ismail, 1993: 67)

Many sacrifices should be made and many challenges should be faced to oppose the tyranny (the term used by Taufiq Ismail. However, in the couplets of the poem "Sebuah Jaket Berlumur Darah' (a blood-smeared jacket), the poet asked the fighters for freedom to oppose the tyranny by saying /Akan mundurkan kita sekarang/ (Shall we 
withdraw now). The poet used the word "kita" (we) as he was involved in the opposition to the New Order government. He did not only say the word "mundur" (withdraw) but was also saying 'Selamat tinggal perjuangan' (Good bye the opposition). There was an impression that the poet used a sarcastic expression to express his feeling. Apart from that, he also used a paradoxical expression to announce such an opposition to the tyranny, that is, "kita" (we). Such a paradoxical expression was also used to criticize "kita" (we) by not only saying 'selamat tinggal perjuangan' (good bye the opposition), but also saying /Berikrar setia kepada tirani/ (promising to be faithful to the tyranny). In addition, he was also saying that he was proud of serving the tyranny by 'mengenakan baju kebesaran sang nelayan' (wearing the shirt which formally indicates that someone who wears it is a fisherman). They poet used such strong cynical and paradoxical expressions to compare 'baju kebesaran' (the shirt indicating that someone who wears it occupies a high rank position) with 'sang pelayan' (the marginalized people or the black color workers).

There were so many banners in different places showing opposition to the tyranny. They had been posted since such a long time before that they looked 'kumal' (rumpled); however, the opposition which they indicated would never come to an end. The flags which were posted 'di atas bangunan-bangunan' (over the buildings) were not only rumpled but had also been 'menunduk' (bowing) as they were sad. The sadness shown by the flags which were posted to symbolize 'perjuangan kita' (our opposition) to the tyranny did not only bow but they had also been displayed 'setengah tiang' ( in the middle of the poles). Such banners and flags symbolized sadness as "perlawanan kita" (our opposition) to the tyranny was avoided by the tyranny.

According to the poet, the message to oppose the tyranny which such banners and flags contained had been 'telah sampai ke manamana' (everywhere); it had reached 'kendaraan' (vehicles), 'abang beca' (the three-wheeled vehicle drivers), 'kuli-kuli pelabuhan' (harbor laborers), the screams made by those who carried 'jenazah ke pemakaman' (the corpses to the cemetery). They all yelled out and intended that such an opposition should be continued /LANJUTKAN
PERJUANGAN/. This poem was ended with the expression /Lanjutkan Perjuangan/ (Keep going the opposition). It was written in capital letters. The poet would like to give emphasis that "kita" (we) should not discontinue the opposition; in other words, we should continue the opposition until the tyranny collapsed.

Taufiq Ismail also criticized the political aspect by comparing the political atmosphere in the era of the Old Order government under President Soekarno with that of the New Order government under President Soeharto, as can be seen from his poem entitled "Berbeda Pendapat" (Having different opinions) as follows.

Oleh orang yang berkuasa, yang berbeda pendapat

Jadi musuh sampai akhir abad

Apalagi oposisi seteru sampai mati

Bung Sjahrir dulu, Pak Ton kini

Lalu Pak Nas, Pak Syafruddin dan Bang Ali

Bertemu di jalan muka dipalingkan

Di resepsi perkawinan dicegah dapat undangan

Telepon disadap, jalur rezeki disumbat

Kendaraan bergulir diikuti ke mana-mana

Hidup bergerak dalam laporan mata-mata (Ismail, 1998:18)

The free translation is as follows:

Those who have power consider that those who have different opinions

Become eternal enemies

They will be enemies until they die

We used to have Bung Sjahrir, now we have Pak Ton

Then we have Pak Nas, Pak Syarifruddin and Bang Ali

They are ignored when they are met in the street They are excluded from those who are invited to attend wedding receptions

Their telephones are tapped; the accesses to their incomes are obstructed

Their vehicles are followed where they go

They are listed in the report prepared by the detectives (Ismail, 1998:18)

The quoted poem above describes that the democracy in the era of the Old Order was 
different from that in the era of the New Order; in particular, they were different in regard to different opinions. According to Taufiq Ismail, although the democratic system was not good during the Old Order era, the government authorities appreciated and respected one another when they had different opinions. Different opinions did not have to lead to hatred and hostility. This was shown by the attitude and behavior of Bung Karno as the President and Mohammad Natsir as the Deputy President. They were often involved in the polemics through mass media; they often had different opinions and concepts. Even the poet described such differences 'nyaris bagai masyrik dan magrib' (almost as the East and the West). The word 'masyrik', meaning the east (KKBI, 2011:886) and the word 'magrib', meaning the west were chosen by the poet to describe different opinions. However, when they met face to face 'berjumpa muka' it seemed that they did not have different opinions, ideas and concepts. The poet described that when they met they looked bright as when an older brother met his younger sibling /Wajah cerah bagai abang dan adik saja/. He described that they were close to one another as when 'abang' (older brother) met 'adik' (younger brother). Such words were used to express that they were close to one another as siblings of the same parents.

Unlike the attitude and behavior of the authorities during the New Order era, those having different opinions meant enemies; furthermore, there would be a permanent hostility among them. In other words, those who had different opinions were enemies; therefore, they should be excluded. Everybody should have the same language and opinion. Those who had different opinions were regarded as rebels. What the people said and did should be the same as what the government said and did; if what they said and did was different from what the government said and did they would be regarded as opposing the government. The poet described the atmosphere at that time (1998) by saying /Kini itu tinggal lagi impian saja/ (now that is a dream only). The closeness, solidarity, and brotherhood which took place, in spite of having different opinions, in the Old Order era were impossible during the New Order government; therefore, he said 'tinggal lagi impian saja' (only a dream which would never come true in the New Order era). The culture of appreciating different opinions and concepts during the Old Order government had been eliminated since forty years before 'dibunuh lima windu lamanya'. Lima windu means 40 years, meaning that the freedom in having different opinions and concepts had been prohibited since 40 years before in the State of Indonesia.

The people were made to have the same opinion as the government for forty years. Those who had different opinions were regarded as eternal enemies /Jadi musuh sampai akhir abad/. Furthermore, those or groups of people who were brave enough to show that they 'opposed' the government, they would become the eternal enemies, meaning that they would become enemies until they died 'seteru sampai mati', as experienced by Pak Nas, Bang Ali and the others. They were brave enough to oppose the government; as a result, their activities were restricted and controlled by the government. Their telephone conversations were tapped 'disadap'; in addition, the access to a better life was blocked 'rezeki disumbat'. The government always followed and observed the activities they did as it was afraid that they would provoke the people to oppose the government.

Sociologically, the poet described the people's social condition at that time (1998) as a condition in which the people were seriously restless. Through this poem, the poet criticized the government that it was always afraid that there would be individuals or groups of individuals who were brave enough to oppose its opinions. The people were made not to have different opinions from the government. As a consequence, the law and human rights were broken.

Through his poems, Taufiq Ismail also criticized the law and human rights. The tyrannical politics implemented during the New Order era, in which different opinions were prohibited, caused the law and human rights to be frequently broken by the government (Sudewa, 2012:266). The law cannot be separated from the human rights as a two-sided coin. The aspects related to the human rights were directly and indirectly broken. Therefore, the social criticisms given by Taufiq Ismail towards the human rights are holistically discussed in this present study. One of the poems written by Taufiq Ismail which is full of criticisms 
towards the law and human rights is entitled "Surat ini Adalah Sebuah Sajak Terbuka" (This Letter Is An Open Letter). Pay attention to the quoted part of such a poem as follows.

Jika ingin saya tanyakan adalah
Tentang harga sebuah nyawa di negera kita
Begitu benarkah murahnya? Agaknya
Setiap bayi dilahirkan di Indonesia
Ketika tali-nyawa diembuskan Tuhan ke
pusarnya
Dan menjeritkan tangis-bayinya yang pertama
Ketika sang ibu menahankian pedih rahimnya
Di kamar bersalin
Dan seluruh keluarga mendoa dan menanti
ingin

Akan datangnya anggota kemanusiaan baru ini

Ketika itu tak seorangpun tahu

Bahwa 20, 22, atau 25 tahun kemudian

Bayi itu akan ditembak bangsanya sendiri

Dengan pelor yang dibayar dari hasil bumi

Serta pajak kita semua

The free translation is as follows:

What I would like to ask is

How much is a soul in our country

Is it true that it is so cheap? It seems that

Every infant that is born in Indonesia

The soul-cord is blown into the navel by God

And the first hard crying is made by the infant

When the mother endures the pain of her uterus In the room when she gives birth to the infant

And all her relatives pray and expect that

A new human member will come

At that time nobody knows

That in 20, 22 or 25 years later

The infant will be shot by its nation

Using the bullet paid for with the money earned by selling the agricultural product

And the taxes which we all pay

$$
\text { (Ismail, 1993: 149-151). }
$$

The tyranny and cruelty of the New Order government were so strong when implementing the government that the poet asked how much a soul was in our country/Tentang harga sebuah nyawa di negara kita/. What was intended by the expression 'negara kita' (our nation) was the nation of the poet himself and the readers, namely, Indonesia. In Indonesia someone's soul was regarded as meaningless. The poet expressed his criticism using an oratorical expression 'Begitu benarkah murahnya?' (Is it true that a soul is so cheap?) The poet felt that how sad and painful the families whose members were killed by the tyranny as it liked without humanity. The poet criticized that the government had never thought about and felt how human beings were born, starting from when they showed their first cries 'menjeritkan tangis-bayinya yang pertama', and how their mothers risked their souls to give birth to them and endured their painful uteruses 'menahankan pedih rahimnya'. In addition, all the family members prayed and happily expected for the arrivals of new human beings 'seluruh keluarga berdoa dan menanti'.

The mother, after going through the process which risked her soul, did not expect that in 20, 22 or 25 years' time, when the baby became an adult, it was shot 'ditembak' by its own nation 'bangsanya sendiri'. Nobody could accept that someone was killed by his/her own nation for nothing. Moreover, what was more painful was that such an infant was killed using the bullet 'pelor' which was bought using the money earned by selling the agricultural product 'hasil bumi' and the taxes which we all had paid 'pajak kita semua'. It was not wrong that the word bullet 'pelor' was used to support such a human tragedy, causing the readers' antipathy towards the government to be getting stronger. The anticlimax of the tragedy was described by saying that blood had led such a baby 'bayi itu' to the world and then blood had also led it to its death / Darah telah mengantarkannya ke dunia/kemudian/ Darah lalu melepasnya dari dunia/. What was meant was that such an infant was born through the blood which the mother sacrificed, and then when it died it was also led by its own blood and even by the flood of hatred /Darah kebencian/ towards someone who killed it or the government.

Another poem written by Taufiq Ismail which clearly and more strongly criticized the law and human rights entitled "Padamu Negeri" (For You Our Country). Pay attention to the quoted part of the poem as follows.

Kami dianiaya bertahun-tahun berkali-bali 
Ramai-ramai dibunuh dan dihabisi Usai kami dibunuh janda-janda kami disakiti Tidak bisa melawan desa kami dibakari Panah mustahil tandingan senjata api Seperti rabies anjing dalam epidemic Sebutlah berapa nama kota lokasi propinsi

Kubur dimana maklumat tak diberi Hidup kami berganti nyeri dan ngeri Mengenang satu malam ratusan ditembaki Mengingat bertahun ribuan dihabisi Jadi setiap menyanyikan lagu ini Tiba pada dua baris terakhir sekali Jiwa raga Cuma pada Tuhan kami beri Sesudah itu terserah Dia sendiri Apa akan dibagikanNya juga pada negeri (Ismail, 1998:35)

The free translation is as follows:

We were maltreated repeatedly for years We were killed and eliminated After we were killed our widows were hurt We could not do anything, our villages were burnt

It was impossible to use arrows to compete firearms

As rabies in epidemic

The names of locations, cities, locations, provinces

Where we were buried were never announced Pains and horrors alternated In one night hundreds were shot In years thousands were killed So every time such a hymn was sung We came to the last two lines We offered our souls and bodies to God After that it is up Him

Whether God would share it with the country (Ismail, 1998: 35)

The poem above reminded us of one of the hymns in Indonesia entitled "Padamu Negeri" (For You the Country), the same as the title of the poem. In other words, it is believed that such a poem was inspired by such a hymn, meaning that the poet would like to show his nationalism and care about the oppressed people to the readers.

The poet tragically and dramatically described that the law and human rights had been broken everywhere in Indonesia by the government. The poet said that we were repeatedly maltreated for years /Kami dianiaya bertahun-tahun berkalikali/. The word 'kami' (we) represented the poet and the common people who were consciously tortured 'disiksa dan dianiaya'. In addition, many of us 'kami' were killed and eliminated 'dibunuh dan dihabisi' for nothing; why we were tortured and even killed. The tragedy and horror were made by the government for the powerless people ('tidak bisa melawan'). Moreover, what made the readers sad was that after we were killed our widows were hurt/Usai kami dibantai janda-janda kami disakiti/, then our villages were burned 'desa kami dibakari'. The poet's description of the common people's suffering and the government's cruelty was perfect.

The people were certainly powerless to face the government using arrows 'panah' (symbolizing the common people) to compete the firearms 'senjata api' (symbolizing the government), meaning that it was impossible for arrows 'panah' to defeat firearms 'senjata api'. The poet described that the people's lives changed into "pain and horror". The poet would like to say that such a condition continuously took place in Indonesia by saying that the government's cruelty to the common people was like rabies in epidemic / Seperti rabies anjing dalam epidemic/.

The poet more clearly and tragically said that in one night hundreds of people were shot 'satu malam ratusan ditembaki' and even in years thousands of innocent people were killed 'dihabisi'. Referring to one of the hymns in Indonesia, that is, 'Padamu Negeri' (For You the Country), and every time it was sung 'setiap menyanyikan lagu ini', the poet was reminded of the expression 'jiwa raga kami' (our souls and bodies)which the hymn contains. In accordance with him, it was believed that our bodies and souls should only be offered to God /Jiwa raga Cuma pada Tuhan kami beri/ to face what was done by the brutal government, meaning that 'kami' (we) would dienot only due to the government but the God's wish 'kehendak Tuhan'. It was up to God what would happen after we offered our bodies and souls to Him. The word 'Dia' $(\mathrm{He})$ starting with a capital letter refers to God, namely, our God (Tuhan kami). From the semiotic point of view, when the poem entitled "Padamu Negeri" (For You Our Country) was ended with a 
oratorical question /Apa akan dibagikanNya juga pada negeri/ (whether He would share it with the country), he intended to ask whether God would share the people's sufferingwith our country ('negeri'), namely, Indonesia.

It seems that, through the poem "Padamu Negeri" (For Your Our Country), the poet would like to show that he was very good at using the vowels (assonance) and intonation to express social criticisms. If viewed from the aesthetical point of view, it is this which has caused such a poem to be having a quality and more interesting to read. It can be seen that the poetic lines quoted above are dominated by the vowel i. Even all the lines are ended with the vowel i. It is one of the strengths of the poems written by Taufiq Ismail; therefore, it is not exaggerated if Darmono (2014:33) said that the poems written by him are poems as well as pictures.

Taufiq Ismail also criticized education through his poems. The reason was that during the New Order government the matters pertaining to education needed to be criticized and corrected as well, as illustrated in the poem entitled "Takut '66, Takut '98' (Being Afraid in 1966, and Being Afraid in 1998). Pay close attention to the following poem.

Mahasiswa takut pada dosen

Dekan takut dengan rektor

Rektor takut pada menteri

Menteri takut pada presiden

Presiden takut pada mahasiswa (1998: 3)

The free translation is as follows.

University students were afraid of their lecturers The Dean was afraid of his/her rector The Rector was afraid of the minister The minister was afraid of the president The president was afraid of the university students

The poem above is similar to what is referred to as mbeling poem (the poem of antiestablishment), which was packaged in the form a parody. Such a poem does not look like a serious one, although, actually, it is a serious one. In this case, the poet expressed his social criticism in the form a parody, making those who were criticized not offended and angry. This poem contained the matters pertaining to higher education, one of which was the relationship between the students and their institutions and who were above them. The poem implicitly described the situation when the New Order regime under the leadership of President Soeharto was about to come to an end. Actually, Soeharto's power was overthrown by the students' movement all over Indonesia.

The fact showed that, as far as the higher education in Indonesia was concerned, the students usually got afraid that they would not pass the courses which particular teachingstaff members were in charge of. It was such a situation which was criticized by Taufiq Ismail by saying that the students were afraid of their lecturers /Mahasiwa takut pada dosen/. The students should not have been afraid of their lecturers as they had free academic rostrum in which they were free to express their opinions both orally and in writing, providing that they were able to be accountable for what they argued.

The poet did not only criticize the students but also the lecturers. The latter were also afraid of who supervised them, namely, the Dean. This was expressed by saying that the lecturers were afraid of the Dean /Dosen takut dengan dekan/. The reason was that it was the Dean who would determine the carrier of the lecturers. In the developed countries, the democratic life was better as a lecturer would never feel afraid of who supervised him/her. Unlike the academic life in Indonesia, in general a lecturer was afraid of who led him/her, namely, the Dean. The Dean was afraid of his Rector as the former was indirectly and directly determined by the latter. This was expressed by the poet by saying that the Dean was afraid of the Rector /Dekan takut dengan rector/. The Rector was afraid of the minister who directly or indirectly supervised him /Rektor takut pada Menteri/. The minister was afraid of the President; the reason was that the former was appointed and dismissed by the latter /Menteri takut pada president/. However, the president was afraid of the students; the reason was that the experience shows that in the New Order era President Soeharto was overthrown by the students. 


\section{RECONSTRUCTION OF THE NATION'S IDENTITY AND CHARACTERS THROUGH THE POEMS WRITTEN BY TAUFIQ ISMAIL.}

From different social criticisms provided by Taufiq Ismail, it seems that he would like to inform the readers that what was criticized should not have taken place in Indonesia. The reason was that what was actually criticized the poet was not the Indonesia's identity and character. He reminded the Indonesian people in general and the government in particular that the government should seriously pay attention to the nation's character which is culturally great in every aspect of life. Indonesia is rich in great 'adiluhung' local wisdoms; therefore, it is well known as a culture-based country all over the world. Its identity and character which every citizen should be proud of is described in brief as follows.

Based on the book entitled Kebijakan Nasional Pembangunan Karakter Bangsa Tahun 2010-2025 (the National Policy of the National Character Building from 2010-2015), identity is the human tithe which potentially grows as long as the mind's eye is clean, healthy, and open. The identity which is affected by environment will grow into a character on which the human way of thinking and behaving will be based. Therefore, it is identity which contributes to the character formation in the forms of thoughts (in the level of concepts), attitude and behavior when facing both internal and social environmental problems.

Apart from giving social criticisms, Taufiq Ismail also implicitly proposed the expected national character, meaning that he was not only able to criticize but was also able to propose a concept or what characterized the national character which should be referred to by every Indonesian citizen in general and the government officials in particular. Such a concept or what characterized the Indonesia's identity was expressed by Taufiq Ismail in his poem written in 1965 entitled "Nasihat-nasihat Kecil Orang Tua Pada Anaknya Berangkat Dewasa" (the Minor Advices Given by the Parents To Their Children Who Are Becoming Adults). Pay attention to the following poem.

Jika adalah yang harus kaulakukan Ialah menyampaikan kebenaran
Jika adalah yang tidak bisa dijual-belikan Ialah yang bernama keyakinan Jika adalah yang harus kautumbangkan Ialah segala pohon-pohon kezaliman Jika adalah orang yang harus kauagungkan Ialah hanya Rasul Tuhan

Jika adalah kesempatan memilih mati

Ialah syahid di jalan Ilahi (Ismail, 1993: 125).

The free translation is as follows.

If there's something you should do

That's the truth

If there's something which cannot be traded

That's referred to as the belief

If there's something which should be broken

That's all trees of tyrannies

If there's someone who you should praise

That's the prophet

If there's an opportunity to choose death

That's a martyr (Ismail, 1993: 125)

The nation's character which was expected by the poet above was formed through consistent and established repetitions of words, as illustrated by the repeated words 'jika' (if) and 'ialah' (that's ..). The repetitions of such words led to such constant sounds and rhythms that the intensity of the messages which the poet ('orang tua') intended to give to his children who were becoming adults 'anaknya (yang) berangkat dewasa' could be more strongly felt. If related to the nation's character described above, it seems that the message which the poet intended to give to his children who were becoming adults 'anaknya yang sedang beranjak dewasa' was that if in the journey of your lives you wanted to do something 'ingin kaulakukan', what you should do was telling the truth 'menyampaikan kebenaran'. From the semiotic point of view, as far as the people's lives which could not be separated from falsehoods and hypocrisies were concerned, you 'kau' should be brave enough to tell the truth 'kebenaran' whatever you would risk as being brave in general and telling the truth in particular was the Indonesia's character.

\section{CONCLUSION}

Taufiq Ismail criticized the economic sector and capitalism, political sector, the law and human rights, and the educational sector. It was such 
sectors which the New Order government broke through the socio-political strength it had. The New Order government was so powerful that it was possible for it to do what it liked (in an authoritative manner). All the power instruments were controlled by the government and the people were too afraid of opposing it.

The poet criticized all the sectors above using the structural elements, meaning that the words used were so accurately and effectively chosen that the social criticisms that his poems contained could be effectively transmitted to the readers. The social criticisms he intended to transmit were packaged in a refined manner and one of which was in the form of a mbeling poem or a parody, making the readers not offended when they felt that they were criticized by Taufik Ismail, who was not only good at exposing social problems but was also good at using various poem forming elements to transmit the intended totality of the messages to the readers.

The poet criticized the Indonesian society's social condition in the era of the New Order government. He employed different poem writing techniques and literary facilities to affirm and deepen the social criticisms which he intended to transmit. Actually, through the social criticisms he transmitted, he intended to reconstruct the Indonesia's identity and character in the past. He expected that all the events happening to the Indonesian society under the pressure of the New Order government will not take place anymore in the future.

\section{ACKNOWLEDGEMENT}

In this opportunity, the writer would like to express his gratitude to Almighty God, Tuhan Yang Maha Esa, that it was His blessing which enabled the writer to complete this article well. Thanks are expressed to Prof. Dr. I Nyoman Darma Putra, M.Litt for his supervision, suggestion, criticism and cooperation during the completion of this article. A word of appreciation should also go to the Directorate of Higher Education for funding this study. It is expected that this article will be useful to the readers and contribute to the development of literary sciences.

\section{REFERENCES}

Alfian, Teuku Ibrahim. (2003). "Sastra sebagai Arena Pertarungan Politik". Dalam Sastra Interdisipliner Menyandingkan Sastra dan Disiplin Ilmu Sosial. Editor: Muh. Arif Rokhman dkk. Yogyakarta: Qalam

Anonim. (2013). Kebijakan Nasional Pembangunan Karakter Bangsa Tahun 20110-2025. Pemerintah Republik Indonesia.

Chambers, Robert. (1983). Rural Development Putting the Last First. Published by Longman Inc.

Damono, Sapardi Djoko. (2014). “60 Tahun Bernyanyi, Bercinta, Mengenang, Menangis, Mengutuk, dan Berdoa". Majalah Sastra Horison, Tahun XLVIII, No. 6/2014, Juni.

Haryono, Edi (ed.). (2009). Ketika Rendra Baca Sajak. Jakarta: Burung Merak Press.

Hawkes, Terence. (1978). Strukturalism and Semiotics. London: Methuen \& Co Ltd.

Ismail, Taufiq. (1993). Tirani dan Benteng. Jakarta: Yayasan Ananda . (1998). Malu (Aku) Jadi Orang Indonesia. Jakarta: Yayasan Ananda

Laurenson, Diana and Alan Swingewood. (1972). The Sociology of Literature. London: Paladin.

Pemerintah Republik Indonesia. (2013). Kebijakan Nasional Pembangunan Karakter Bangsa Tahun 20110-2025.

Pradopo, Rachmat Djoko. (2002). Kritik Sastra Indonesia Modern. Yogyakarta: Gama Media.

Soetrisno, Loekman. (1997). Kemiskinan, Perempuan, dan Pemberdayaan. Yogyakarta: Kanisius.

Sudewa, I Ketut. (2012). "Kritik Sosial dalam Puisi dan Drama W.S Rendra 1970-an-1990-an". Denpasar: Disertasi Unud.

Teeuw, A. (1984). Sastra dan Ilmu Sastra Pengantar Teori Sastra. Jakarta:Pustaka Jaya.

Tim Redaksi Kamus Besar Bahasa Indonesia Pusat Bahasa. (2011). Kamus Besar Bahasa Indonesia Pusat Bahasa (Edisi Keempat). Jakarta: Departemen Pendidikan Nasional. 